\title{
"UNUSUAL, UNSTABLE, COMPLICATED, UNRELIABLE AND TEMPORARY" REINTERPRETING THE EBB AND FLOW OF GLOBALIZATION
}

\author{
Michael D. Bordo \\ Catherine R. Schenk \\ Working Paper 29114 \\ http://www.nber.org/papers/w29114
NATIONAL BUREAU OF ECONOMIC RESEARCH
1050 Massachusetts Avenue
Cambridge, MA 02138
July 2021

For helpful comments, we thank Harold James, Chris Meissner, and Robert McCauley. The views expressed herein are those of the authors and do not necessarily reflect the views of the National Bureau of Economic Research.

NBER working papers are circulated for discussion and comment purposes. They have not been peer-reviewed or been subject to the review by the NBER Board of Directors that accompanies official NBER publications.

(C) 2021 by Michael D. Bordo and Catherine R. Schenk. All rights reserved. Short sections of text, not to exceed two paragraphs, may be quoted without explicit permission provided that full credit, including $\odot$ notice, is given to the source. 
"Unusual, Unstable, Complicated, Unreliable and Temporary" Reinterpreting the Ebb and Flow of Globalization Michael D. Bordo and Catherine R. Schenk

NBER Working Paper No. 29114

July 2021

JEL No. F02,F33,N10

\begin{abstract}
In 1919, John Maynard Keynes wrote his famous tract The Economic Consequences of the Peace. In that work, he anticipated the collapse of the first era of globalization that began in the midnineteenth century. He admonished the short-sighted assumption that these years of relative peace and prosperity for many was a permanent norm, interrupted only briefly by the Great War. The diplomatic failures, lapses in leadership, and promotion of narrow interests and vision outlined by Keynes underpinned his prediction of a backslash of economic nationalism, trade protectionism, and recession.

The paper revisits the turning points in the evolution of the global economic system since 1919 by focusing primarily on the evolution of the international monetary system and policy cooperation/coordination. We identify three disruptions and examine how each prompted a change in the underlying ideology about how the international monetary system should organize: World War I, Bretton Woods, 1970s Great Inflation and Managed Floating. Each turning point was characterized by different forms and institutions of cooperation, how rules (either explicit or implicit) were designed and implemented, and the crucial importance of the historical context.
\end{abstract}

Michael D. Bordo

Department of Economics

Rutgers University

New Jersey Hall

75 Hamilton Street

New Brunswick, NJ 08901

and NBER

bordo@econ.rutgers.edu

Catherine R. Schenk

Faculty of History, George Street

Oxford OX1 2RL

United Kingdom

catherine.schenk@history.ox.ac.uk 
'Unusual, Unstable, Complicated, Unreliable and Temporary' Reinterpreting the Ebb and Flow of Globalization ${ }^{1}$

"The power to become habituated to his surroundings is a marked characteristic of mankind. Very few of us realize with conviction the intensely unusual, unstable, complicated, unreliable, temporary nature of the economic organization by which Western Europe has lived for the last half century. We assume some of the most peculiar and temporary of our late advantages as natural, permanent, and to be depended on, and we lay our plans accordingly." (Keynes 1919)

\section{Introduction}

The opening sentences of Keynes' influential 1919 cri de Coeur, The Economic Consequences of the Peace, anticipated the collapse of the structures of the international economy that had prevailed from the later $19^{\text {th }}$ century. Unprecedented flows of people, goods and capital to a wide geographical area during the first era of globalisation had created expectations of growth and emphasized the importance of open international economic relations for creating that growth and opportunity. Keynes admonished the short-sighted assumption that these years of relative peace and economic prosperity for many was a permanent norm, interrupted only briefly by the Great War. He foresaw in the Versailles Treaty the suspension of globalisation as more prolonged or even perhaps permanent. Keynes was writing at the defining moment of the $20^{\text {th }}$ century, in the middle of what came to be viewed by some as a 30 -year war. The diplomatic failures, lapses in leadership and promotion of narrow interests and vision outlined

\footnotetext{
${ }^{1}$ For helpful comments we thank Harold James, Chris Meissner and Robert McCauley.
} 
by Keynes in the Economic Consequences of the Peace underpinned his predictions of a

backlash of economic nationalism, trade protectionism and recession.

This paper revisits the turning points in the evolution of the global economic system in the century since 1919 by focussing on the evolution of the international monetary system and policy cooperation/coordination. While there is but a fleeting reference to the international monetary system in Keynes' 1919 treatise, this focus is justified by how Keynes interacted with the ensuing efforts to restore the pre-war system that he criticises in Consequences of the Peace. This includes his 1925 sequel, The Economic Consequences of Mr. Churchill and his direct role in the design of the post-1945 international monetary system. We identify three disruptions and examine how each prompted changes in the underlying ideology about how the international monetary system should be organised. Each turning point was characterised by different forms and motivation of cooperation, how rules (either implicit or explicit) were designed and implemented, and the crucial importance of the historical context. Finally, the paper explores how the dominant interpretations of the past shaped policy reactions in the present and concludes with some lessons for today.

\section{Turning Point I: World War I and the End of the First Era of Globalization}

Keynes started The Economic Consequences of the Peace with a description of how the world before 1914 marked the apogee of the first era of globalization..

"What an extraordinary episode... the internationalization of which was nearly complete in practice ... The inhabitant of London could order by telephone, sipping his morning tea in bed, the various products of the whole earth, in such quantity as he might see fit, and reasonably expect their early delivery upon his doorstep; he could at the same moment and by the same means adventure his wealth in the natural resources and new enterprises of any quarter of the world, and share, without exertion or even trouble, in their respective fruits and advantages ; 
... But, most important of all, he regarded this state of affairs as normal, certain, and permanent, except in the direction of further improvement, and any deviation from it as aberrant, scandalous, and avoidable.." (pages 4-5)

In retrospect, Keynes' 1919 description of the gold standard era as 'unusual, unstable, complicated, unreliable and temporary' seems remarkably perceptive. The system worked best for countries (like Britain) at its core and it was supported by the geographic breadth of the British empire and by the persistence of Britain's open trade policy despite rising protectionism in Europe and the North America. Already by the end of the $19^{\text {th }}$ century restrictions on trade and migration were undermining the key sources of economic prosperity of the 'golden age' of the first globalization. This retreat from globalization was accompanied by rising political and strategic hostility in Europe that brought an abrupt end to this period of relative global prosperity. In 1914 the first era of globalization crashed to a close with World War I and then the Great Depression but many of the seeds of its destruction were planted beforehand. In turn, globalization may have contributed to the wave of nationalism that led to World War I and even the second part of the Thirty Years war (Temin 1989). O'Rourke and Williamson (1999) argued that the process of globalization planted the seeds of its own destruction (see also James 2002) through the convergence of prices and wages that challenged incumbents. By the end of the century, the era of mass migration gave way to a wave of restrictions on the movement of people. The May 1882 US Chinese Exclusion Act was the culmination of decades of social and political lobbying against Chinese immigrants, in particular. Soon afterwards, the US Immigration Act of August 1882 introduced the concept of 'inadmissible 
aliens' who were deemed to undermine the living standards of previous, mainly white, settlers. At the end of 1901, Australia, with a much shorter history of immigration than the US, passed its own Immigration Restriction Act aimed at stopping non-white immigration. ${ }^{2}$ The political and social limits to globalization through migration had therefore already been reached in the decades before 1914. The most potent symbol of the era of mass migration, the Statue of Liberty in New York harbour, was finally completed in 1886, four years after the immigration back-lash made it into the US law book. Emma Lazarus' poem referring to the 'huddled masses' coming to the US (written in 1886 after the Immigration Act) was added in 1901. In many ways the Statue of Liberty marked a symbolic end of an era rather than a celebration of the enduring spirit of migration building the American state.

Financial globalization also experienced a backlash. Open capital accounts were associated with private investment booms and busts leading to financial crises (both currency and banking crises). Capital flowed from the capital rich countries of Western Europe to the capital scarce countries across the Atlantic in North and South America or to former colonies, mainly in Australasia or Eastern Europe. But many lacked the institutional development to fully convert the new funds into productive investments and hence the capital inflow fueled asset price booms (Bordo and Meissner 2017). In the absence of central banks (e.g. in the US, Canada, Australia) or in the case of countries which had them but were unable to adhere to the gold standard (in Southern Europe, Latin America) currency crises and banking panics could lead to severe economic distress and sovereign debt crises. Moreover, under the classical gold standard, the world price level went through long swings of deflation and inflation reflecting

\footnotetext{
${ }^{2}$ Other countries introduced similar restrictions after 1919.
} 
the growth of the real economy relative to the glacially slow growing world gold stock. Gold shortages (deflation) would ultimately, via the Commodity Theory of Money, lead to technical innovation in gold mining and new discoveries (Bordo 1981, Rockoff 1984). But the timing of these events were adventitious (Keynes 1925) rather than synchronized with the needs of the global economy. In the US and elsewhere the Great Deflation of 1873 to 1896 led to a populist outcry against gold and in favor of free silver and bimetallism (Eichengreen 2018).

The first era of globalization and the gold standard that underpinned it, were clearly complex and unstable and already appeared temporary to Keynes by 1919. But this was a view that did not gain traction among policy-makers. They sought to return to the relatively rapid growth of the mid-late $19^{\text {th }}$ century by recreating the stable exchange rates and gold anchor after 1919 . There was less public or political enthusiasm, however, for the free trade, open capital markets and migration that had been fundamental to the early successes of this era.

The eruption of the First World War in 1914 confirmed the end of the first era of globalization. Virtually all countries left the gold standard de jure or de facto once Britain suspended convertibility of sterling to gold after the financial crisis in 1914 (Roberts 2013). The British and other belligerents sold most of their outstanding investments in the US (and other emerging countries) to pay for the war (Silber 2007). Both exchange controls and capital controls were widely imposed (Eichengreen 1992). Free trade turned into managed trade and tariffs were raised further (e.g. the Fordney McCumber Act in the US in 1922). Free longdistance migration all but ceased. Moreover, the balance of economic power was permanently shifted from the UK to the US as leading global creditor, which posed huge political challenges for an American population distant from the hostilities that had ravaged Europe and living in a 
country built on a sense of individual and national ambition above internationalism. As Keynes emphasized, the potential to restore what appeared to be 'normal' conditions of open trade and payments after the war was further hampered by the way the war was financed through the accumulation of debt among allied nations that depended on reparations from the defeated powers to be repaid.

The interwar gold standard was a deliberately constructed system arising from a series of international congresses after 1919 (Lausanne 1920, Genoa 1922, Tripartite Agreement 1936). The need for cooperation was increasingly recognized as the German economy floundered, the Bolshevik Revolution brought a violent end to the Russian empire and war debts strained the global financial system. The ambitious League of Nations provided a bureaucratic locus for gathering intelligence, identifying problems and seeking cooperative solutions, but the lack of engagement by the US administration was a major handicap to its effectiveness in promoting international cooperation despite the passionate efforts of many of the bureaucrats (Clavin 2013). Schisms within the League led to the creation of the Bank for International Settlements in 1931 as an alternative venue for European central bank cooperation (Toniolo 2009). Nevertheless, there were some lasting legacies, including new central banks in a range of emerging market economies in South America and Australasia, which were set up based on the British (Niemeier) or US (Kemmerer) models to help to manage the international monetary system (Singleton 2011). The bureaucrats and researchers also formed a cohort that reemerged in the post-1945 era to rebuild international economic relations (e.g. Jean Monnet, Jacques Pollak, Robert Triffin) and left an intellectual legacy that Pauly (1996) argued foreshadowed the Bretton Woods institutions. 
Holding large gold reserves was out of reach for most countries. In the pre-war period, this challenge had been partly overcome by the use of sterling as the dominant global currency and trust in the ability of the Bank of England to sustain the gold value of the pound. After 1919, this could no longer be assumed. The interwar system formally accepted the use of sterling and the dollar (and to a lesser extent the franc) as foreign exchange reserves in a gold exchange standard, but faith in the ability of the Bank of England to protect the parity was ephemeral. The new US Federal Reserve made a short-lived effort to promote the dollar as the key international currency (Eichengreen and Flandreau, 2009) after successfully returning to the gold standard in 1919 at the pre-war parity, but sterling remained the main currency of settlement and unit of account for international trade.

In the end, the interwar gold exchange standard also proved "unstable, temporary and unreliable". Nominal exchange rate pegs that did not reflect underlying economic realities or relative price competitiveness and became caught in the turmoil of the tangle of war debts and reparations. Thus France returned to gold at an undervalued parity with a central bank law that sterilized gold flows (Moure, 1996), while Britain returned to sterling at a rate that Keynes considered damagingly overvalued (Keynes, 1925). The weakness of the British economy (and therefore sterling) and the inability to resolve the war debts-reparations tangle created by the Treaty of Versailles brought the unstable and fragile system crashing down in 1931.This time even Britain abandoned free trade and the world lurched into economic nationalism. For Britain, the concept of nationalism extended to the Empire, which sustained global trade for many developing economies through imperial preference. But the depression in agricultural prices and protectionism elsewhere created a downward spiral of trade that left no country 
untouched (Kindleberger 1975; Albers 2020; de Bromhead et al). The unresolved peace settlement of 1919 was exposed, as economic nationalism fed into political populism and renewed conflict in 1939. Within months of the onset of World War II, the next phase of international economic cooperation was underway in bilateral negotiations between Britain and the US over the next post-war settlement.

\section{The Second Turning Point: World War II and the Bretton Woods System}

The complex multilateral structures of the League of Nations and the technocratic turn in economic diplomacy found their echoes in the planning for a postwar international economic system. Both the US and UK sought to establish more powerful collective institutions that would have the financial as well as bureaucratic resources to govern a refreshed multilateral global economy. By this time, the predictions in Keynes' 1919 treatise seemed to have come true, except for his claim that Britain would remain immune and separate from the devastating impact on the European continent ( $\mathrm{p} . \mathrm{xx})$. The prevalence of unemployment, political extremism and nationalism that characterised the 1930s were the main targets for postwar planners (Arndt, 1944). In West European states these imperatives led to elaborate welfare states that required substantial public funding and taxation and strengthened the nation state (Milward, 1999). On both sides of the Atlantic there was also a commitment to integrate Germany back into the European economy to ensure a more sustained recovery for both Germany and its European trading partners.

What followed was a high point of international economic cooperation designed to overcome the failures of the inter-war period. The Cold War circumscribed the extent of this cooperation, 
but also made it more urgent among the capitalist western powers, first as a defence against creeping communism and then later as evidence of the success of the capitalist system vis-à-vis the communist system of the Eastern Bloc. As in the classic gold standard era, most participants of the international monetary system from 1950-1970 experienced rising incomes, economic growth, and a rapid increase in international trade, particularly in manufactures. But, like Keynes' verdict on the $19^{\text {th }}$ century globalisation, this era of relative exchange rate stability also proved "unusual, unstable, complicated, unreliable and temporary". These characteristics arose from flaws in the structure of the international monetary system designed for an imagined restoration of the global order that did not in the end emerge after 1945.

There were three main points of general consensus among planners for the post-war. First, ambitious plans were made for a carefully managed global monetary system by planners who still assumed that stable exchange rates for convertible currencies were needed to allow the maximum gains from multilateral trade. The second area of consensus was in the faith in freer trade to promote growth and employment as well as sustaining a more lasting peace. ${ }^{3}$ Finally, after the financial crises of the 1930s there was distrust of short term capital flows as destabilising influences that would undermine stable exchange rates. These areas of consensus were recognised in particular by Keynes and reflected in his early writings on the organisation of the international monetary system such as The Economic Consequences of Mr. Churchill (1925).

The design of the Bretton Woods system was heavily influenced by interpretations of the causes of the Great Depression of the 1930s (Gardner, 1956, Steil 2013). The main lessons for

\footnotetext{
${ }^{3}$ Although Keynes (1933) had been quite protectionist.
} 
the international monetary system were that unstable exchange rates were damaging, competitive devaluations and 'hot money' had to be prevented, and the system should be freed from the depressive effect of "Golden Fetters" (Nurkse 1944, Eichengreen 1992, Albers 2020). .

The lessons from Versailles meant that even before the US joined the Second World War, the WWI system of war debts was avoided between the US and the Allied powers as part of the expression of common commitment to freer trade after the war. Thus the avoidance of debts in return for support from the US was enshrined in formal agreements with Britain (Atlantic Charter 1941, Mutual Aid Agreement 1942). Nevertheless, British war debts to the Empire and Commonwealth still featured as defining elements in the post-war settlement since they increased Britain's overseas liabilities well beyond their ability to repay them in foreign exchange or to supply goods to redeem them through trade (Schenk 2010, Pressnell 1987). These so-called Sterling Balances became a symbol of the decline of Britain's postwar international economic position and the focus of multilateral cooperation after the War.

The design of the international system aimed to ensure the freer flow of goods while using exchange controls to prevent "hot money" movements in short term capital. It was also crucial that Europe was united economically (if not politically) through freer trade. The US did not advocate free trade, but a 'freer' trade regime that eliminated discrimination (against the US) and bilateralism. The British imperial preference system was gradually eroded in the 1950s, setting the stage for constitutional decolonisation in the decade that followed (Schenk 2010). Meanwhile, Keynes' ideas of fiscal dominance and demand management policies fitted well with the moral and political imperative of Western governments to deliver welfare states, full employment and prosperity to their populations. 
The contrast between the British (Keynes) and American (White) plans for the post-war institutional structure emphasise each nation's priorities, but they also had many similarities (Gardner 1945, Pressnell 1987, Horsefield 1969). Among the most fundamental areas of agreement was that the international monetary system required a formalised, inclusive institutional structure that would reflect the US predominance as the world's largest creditor. Despite the failure of the League of Nations to sustain international economic cooperation in the inter-war period, the faith in formal multilateral economic institutions was imbedded in the wartime planning for peace. Both plans aimed to avoid the economic nationalism that had plagued the 1930 s by providing short term finance for short term balance of payments problems. Keynes devised a much larger pool of liquidity with more symmetric treatment of surplus and deficit countries to benefit countries like the UK, which would emerge from the war substantially weakened. White, in contrast, proposed a more limited contributory fund with the US dominating its governance as the world's largest creditor and able to apply pressure on deficit countries to correct their domestic economies. Both plans also had mechanisms to deal with the debts to the Empire and Commonwealth that the UK had built up during the war, although in the end both governments insisted that the sterling balances be treated separately (Schenk 2010: 40-42). Ultimately White's vision dominated as a more politically manageable solution, especially for an American population exhausted and frustrated by the European wars (Steil, 2014).

The framework was hammered out in a series of meetings that increased in size between 1942 and 1944. This triumph of economic diplomacy ultimately brought representatives of 44 countries together at Bretton Woods New Hampshire in July 1944. The process was in stark 
contrast to the 1919 economic settlement described by Keynes, which took place after the cessation of hostilities, where only four major powers were represented, the Americans were underprepared and the details were delegated to a reparations commission that took two more years to set the amount, by which time the reparations were inextricably intertwined with the ability of the victorious powers to repay war debts. It was also in stark contrast to the restoration of the interwar gold exchange standard, which (despite several summits) lapsed into ad hoc, politically inspired choices of currency pegs to gold. A key goal of the post war period was therefore to create a framework for cooperation and coordination underpinned by credible rules to ensure a lasting and prosperous peace (Giovannini 1993).

Nevertheless, the system designed at Bretton Woods never operated as planned (Gardner 1956). The task of reconstruction after the war was delegated to an International Bank for Reconstruction and Development. This had the advantage of insulating the key international monetary institution, the International Monetary Fund (IMF) from the burdens of post-war reconstruction but also left the financing of this crucial transition period largely in limbo. There was an open and rolling deadline for countries to adhere to the convertibility at pegged exchange rates, which was required to restore multilateral trade and payments. This ended up lasting for twelve years in the case of Western Europe. Secondly, the IMF was the framework for the multilateral payments system, designed to support the more liberal, non-discriminatory trade system announced in the 1941 Atlantic Charter. But completion of the International Trade Organisation foundered on the waning enthusiasm for international compromise by 1946 and the realities of the challenges of post-war national recovery. The ITO was never ratified. 
The 1946 Anglo-American Loan Agreement was Keynes' final intervention in global political economy. The negotiations in Washington exhausted him and the outcome was a disappointment. In echoes of his verdict on Versailles, in May 1945 Keynes identified three options for Britain after the war: 'Starvation Corner', 'Temptation' or 'Justice'. The first would see Britain retreat into austerity and repudiate its debts, the second would add to the debt by borrowing from the US. 'Justice' would entail cancelling a quarter of Britain's wartime debt, funding half, a grant from the US to reimburse British expenditure before the Lend-Lease Act had become operable and a smaller US loan on generous terms (Pressnell 1987). Neither the Bank of England nor the UK Labour government wanted publicly to be seen to be considering repudiating its wartime debts, while the Americans sought some cancellation as a condition of the loan. Keynes continued to seek a 'Justice' solution, albeit reduced in scale, including cancellation of a proportion of Britain's wartime debt in return for making sterling more convertible and a large US loan but he did not find support from London (Schenk 2010: 47-53; Skidelsky 20xx). After 3 months of negotiations led by Keynes, Sir Edward Bridges arrived in Washington from London to take over. A week later, Britain had fallen into 'Temptation' with a large loan, no settlement of war debts and a commitment to introduce convertibility on current account within a year.

Keynes died just over four months later from a heart attack at his home in Sussex aged 63. He did not live to see the run on the pound in July-August 1947 that prompted the reintroduction of exchange controls after only a few weeks. The lesson drawn across Western Europe from the sterling crisis of 1947 was that the convertibility required to adhere to the core articles of the Fund had to be postponed indefinitely. Instead, regional solutions like the 
European Payments Union and the Sterling Area facilitated multilateral payments and the rapid liberalisation of trade. While this ad hoc system did not align fully with the vision of Bretton Woods, it did provide the foundations for freer trade for Western Europe, the British Empire and Commonwealth and North America.

There followed two decades of sustained economic growth, driven by the reduction in quotas and tariffs on international trade, the spread of technological innovation from the US, and Japanese and European technological catching up to the USA. With the help of cooperative efforts like Marshall Aid, European integration, the IMF and regional payments systems, the perils of a repeat of Keynes' 1919 scenario seemed to have been avoided. But the international monetary system was ultimately torpedoed by the failure of the US, at the system's core, to follow credible, sound financial policies during the 1960s.

In 1919 Keynes had identified the start of an enduring asymmetry between the US and Europe and the periodic failure of American leadership commensurate with its economic power. The pegged exchange rate era from 1959-1971 proved to be "unstable, complicated, unreliable and temporary" primarily because of the inability of countries to subordinate their national interests to collective efforts to stabilize exchange rate rates. Thus, there were periodic adjustments to pegged rates, but they tended to come only after a build-up of market expectations with disruptive effects. The conflict between national and international interest was reflected in the persistent dispute between Germany (often with the Netherlands, Switzerland, France) on one side and the US on other over which side should adjust its policies to stabilize exchanges (Germany to inflate or the US to deflate). The identification of an 'exorbitant privilege' (Rueff 1967, McCauley 2015) provided by the dollar's dominant place in 
foreign exchange reserves seemed to many European observers to allow the US to escape the constraints of the pegged exchange rate system. This had been foreseen by Keynes in his proposal for a 'neutral' international unit of account (Bancor, with a fixed gold value) in his 1942 International Clearing Union scheme. Ultimately, the US took unilateral action in August 1971 by suspending gold convertibility, threatening tariffs and a retreat to economic nationalism if other countries did not adjust their exchange rates to take pressure off the dollar (Bordo 2018).

But the end of the Bretton Woods system arguably started soon after it began operating as planned. By 1961, within two years of European states meeting the convertibility terms of the IMF Articles of Agreement, discussions were already under way for how to reform the system as it revealed its instability (Triffin 1960). For the international monetary system, the pegged exchange rate framework based on the dollar that emerged after European countries declared current account convertibility in late 1958 was faulty and required fresh cooperative efforts to prop it up. But instead of the IMF, the G10 and the Bank for International Settlements became the locus of plumbing solutions to the strains caused by the dollar's link to gold, the shifting balance of economic power between the US, Germany and Japan and the retreat of sterling as an international currency.

The most effective solutions came from the G10 central bank governors at the Bank for International Settlements (BIS). It was here that the Gold Pool was formed in 1962 for G10 central banks to intervene in a coordinated way in the London gold market to sustain the official dollar price of gold, which was the foundation of the Bretton Woods system. In this sense, during most of the years of its operation the gold-dollar exchange rate regime did not 
function as planned at Bretton Woods. After six years the market finally toppled the Gold Pool in March 1968 and the fixed gold price was limited to transactions between central banks and through the IMF while the rest of the world operated with a market-determined gold price for the dollar. (Toniolo 2005, Bordo et al 2019). The BIS also provided the meeting place for central bank governors to arrange bilateral currency swaps and multilateral lines of credit to help the retreat of sterling as an international currency without destroying the international monetary system as a whole. ${ }^{4}$ Britain and other European states drew on their quotas at the IMF, but often as a back-stop to the less conditional support arranged quietly in Basel (Toniolo 2005, Schenk 2010). In terms of scale, the support in the November 1964 for sterling amounted to the equivalent of $\$ 31.7$ billion in 1997 which can be compared to the $\$ 40$ billion bail-out of Mexico by the IMF, the BIS, the World Bank and Swaps in that year. From the early 1960s, the Federal Reserve arranged central bank swap facilities in current values and in the early 1970s these bilateral swap facilities amounted to the equivalent of over 20 per cent of global foreign exchange reserves and then declined (McCauley and Schenk 2020, Bordo et al 2015).

The efforts of the G10 finance ministers to reform the international monetary system in more permanent ways was much less successful than those of central bankers. They delegated technical matters to deputies but were still unable to resolve the fundamental problems in the global system (Solomon 1982, James 1996). Their main contribution was to launch the SDR just as the pegged exchange rate system fell apart and the inflation took hold. The political compromises in the design of the SDR meant that it was not as useful as had been hoped and

\footnotetext{
${ }^{4}$ This cooperation extended well beyond Bretton Woods: the final support arrangement for sterling was launched in February 1977 (Schenk 2010).
} 
did not relieve the system of its reliance on the US dollar with all the challenges and asymmetries this imposes (Schenk 2010). Had the US been able to commit to a policy of price stability during the 1960 s, the system could probably have survived longer with these adaptations (Despres, Kindleberger, Salant, 1966, McKinnon 2015, Bordo 2018). This serves to highlight the 'unstable and complicated' nature of the Bretton Woods compromise, which relied on reconciling the domestic priorities of the US policy-makers with the needs of the global economy. Recognising the asymmetry in the global system from the time of the Versailles Treaty in 1919, when the US had power but failed to provide effective leadership, Keynes had sought to introduce a more balanced structure that avoided relying so heavily on the US, but his innovative approach was in the end not feasible in the post-war political and economic climate.

\section{The Third Turning Point: The 1970s Great Inflation and Managed Floating}

The collapse of the Bretton Woods System in 1971-1973 was in part brought about by the U.S. shift to an inflationary stance in the mid-1960s and neglecting the rules as the center country in the pegged exchange rate system. The end of the gold anchor in March 1968, realignment of the DM in 1969 and the float of sterling in 1972 all pulled the system apart. The US administration's effort to force other countries to adjust to US inflation did not convince the markets and the new, more flexible pegs set under the Smithsonian Agreement in December 1971 quickly unwound. There is an extensive literature on the Great inflation that followed through the 1970s (Bordo and Orphanides 2013). Candidates for blame include flawed monetary policy by central banks trying to manipulate the Phillips curve tradeoff to achieve full 
employmentor the accommodation of supply shocks, in particular the six-fold increase in the price of oil in 1973-74.

The Great Inflation marked the abandonment of the Keynesian consensus in policy-making that had spread from the 1950s (Clarke 1990). Keynes, himself, had put little emphasis on exchange rate policy in The General Theory (1939) but his contribution to the design of the Bretton Woods system concurred with the assumption that stable or pegged exchange rates was the most desirable framework. This premise had been fundamental to economic orthodoxy since the 1850s, but it disappeared quickly in the 1970s. The new orthodoxy of capital account liberalization was quick to catch hold partly because it merely recognized the status quo, in which the Eurocurrency market had already risen above the regulatory reach of national monetary authorities (Schenk 2010b).

The Keynesian world of pegged exchange rates, capital controls and international cooperation had disappeared by the 1980s. But the consensus during the 1970 s can be overstated. The US moved resolutely to a managed float, albeit with periods of intense intervention (e.g. 1975-78) (Bordo et al 2015). But Western Europe drew closer to monetary union (an irrevocably fixed exchange rate system) among European Community members from 1969. Other countries caught in the middle sought middling strategies, such as retaining a peg to the dollar or, when that became unstable, to a trade-weighted basket of currencies (Schenk and Singleton 2011).

During the 1970s, policy makers were unsuccessful in reducing inflation in part from following doctrine, later deemed to be flawed (Meltzer 2010) i.e.the Phillips curve and the belief in cost push forces as the key cause of inflation, to be dealt with by wage and price 
controls). In the UK, policy-makers followed Nicholas Kaldor's (1971) view that expansionary money financed fiscal policy could raise the growth rate while inflation could be suppressed by controls. More fundamentally the Great Inflation persisted so long because of the unwillingness of monetary authorities to follow the tight monetary (and fiscal) policies needed to break the back of rising inflationary expectations for fear of the recession and unemployment that would occur. This led to a ratcheting up in inflation and inflationary expectations as the Federal Reserve (and other central banks) when facing a rise in inflation tightened and then when the economy soured, loosened too soon.

On the international scene, high and variable inflation made exchange rates volatile too. This reflected Milton Friedman's (1953) view that floating exchange rates only work if they are accompanied by stable domestic macroeconomic policies. Deliberations at the IMF in the early 1970 s to restore the par value system as well as exchange market intervention were doomed to failure in the face of divergent national economic policies. In 1971, the IMF formed the Committee of 20 to broaden the discussions on reforming the international monetary system beyond the G10. Its deliberations became bogged down in technical details and internal dissention during the collapse of the pegged exchange rate system, but its proposals to reinvigorate the SDR came to partial fruition (Schenk 2017). In 1974 the valuation of the SDR valuation was changed from a weight in gold to a basket of 16 currencies (reduced to 5 in 1981) and with a market interest rate attached to make it more appealing. On the other hand, the C20's proposal to create a substitution account to help the SDR take over more of a role as a global reserve currency from the dollar was debated throughout the 1970s but ultimately lost 
traction in the early 1980s as the dollar exchange rate strengthened (McCauley and Schenk, 2015).

The upward spiral in inflation and the downward spiral in the dollar exchange rate ended with the Volcker shock of October 1979. As chair of the Federal Reserve, Paul Volcker followed a tight monetarist monetary policy by cutting the monetary base and allowing interest rates to rise to above $20 \%$. This created serious recession between 1979 and 1982 which led to double digit unemployment rates and prompted the largest sovereign debt crisis in history among developing economies, but it did succeed in drastically reducing inflation by the mid-1980s (Schenk 2017). Similar policies were followed by Margaret Thatcher and Alan Walters in the UK in 1980 and in Canada and other countries. By the end of the 1980s virtually all advanced countries had returned to low inflation. These actions ushered in the era of monetarism, which then spread in amended forms from the US to the rest of the world. During this period, the success of the credibility of low inflation policies was buttressed by a new paradigm for monetary policy based on central bank independence (CBI), inflation targeting (IT) and floating exchange rates.

Despite Friedman's views that the pursuit of stable rule-like domestic policies obviated the need for international monetary policy coordination, the G7 continued its efforts to coordinate fiscal and monetary policies to stabilize exchange rates in the Plaza and Louvre Accords in the 1980s. This attested to the enduring attraction of international monetary cooperation to stabilize exchange rates. In both cases, the effects were less than was hoped. It proved easier to talk the dollar down in the Plaza Accord (1985) than to convince markets that it was undervalued in the Louvre Accord in 1987 (Truman 2016, Schenk 2017). The impact of the G7 
pressure on Japan to forego its national economic interest in the pursuit of an appreciation of the Yen against the dollar prompted a financial crisis that left the Japanese economy in the doldrums for over a decade.

The emerging market crises of the 1990s confirmed that the international economic system imagined by Keynes had disappeared. Where countries persisted with pegged exchange rates in the 1990s (such as in Russia, East and Southeast Asia, South America) a series of damaging currency crises ensued as the dollar strengthened on the basis of the Fed following domestic policy priorities, leaving emerging market currencies overvalued. Their efforts to hold on to pegged rates with open capital markets failed. By the 2000s (after the Euro finally eliminated most of the national currencies of the EU), floating or managed floating exchange rates had spread further (Bordo and Schenk 2017).

It is important to recognize that the crises of the 1990s and 2000s were mainly through the capital account due to the liberalization of capital markets rather than Keynesian shocks through the current account. The inexorable financialization of the global economy made the Keynesian world of capital controls and international cooperation seem a mere historic relic. Indeed, the IMF began to see its role as having shifted from financing current account shortfalls to stemming capital account crises. The 2007-08 financial crisis was fundamentally not an international monetary issue, although there were substantial global imbalances in the 2000s.

\section{Conclusions:}

Keynes' The Economic Consequences of the Peace has resonated with policy-makers and the public ever since its publication. It continues to be implicitly or explicitly referenced in the 
efforts to promote international economic cooperation in the aftermath of crises through the century. The accuracy of its prediction that an irrational promotion of conflicting national interests would result in economic disaster for the people of Europe has weighed heavily on policy-makers ever since. The history of the $20^{\text {th }}$ century demonstrates that international economic cooperation itself is not unusual, but it does tend to be "unstable, complicated, unreliable and temporary" because tensions inevitably arise between national and international objectives. While these interests might correspond in the wake of a crisis or emergency (partly due to the lessons learned from Keynes' critique of the 1919 settlement) domestic political as well as economic objectives will ultimately dominate despite the construction of elaborate international institutions to overcome or to mediate these conflicts.

An exception is the more functional, but limited form of cooperation evident in the Bank for International Settlements, particularly in the 1960s when central bankers from the G10 deliberately tried to insulate themselves from political influence by focusing on technical rather than system cooperation and by restricting the pubic transparency of their deliberations. This is in marked contrast, for example, to the G10 finance ministers' deliberations in the 1960 s to reform the international monetary system, which were prolonged, expensive and ultimately unproductive.

A further theme of Keynes' treatise is the peril of making economic policy without reference to the underlying economic realities. His book therefore sets out detailed data to demonstrate the potential for Germany to meet its reparations payments. For him, this use of evidence is important because it shows how divorced from a rational perspective the settlement had become. The belief in the power of data-driven economic policy-making was subsequently 
reflected in the extremely complex structures of the League of Nations with its many technical committees collecting a bewildering amount of data from its member countries to serve as a rational basis for policy-making.

Keynes was critical of all four leaders at Versailles and of their advisors. He identified the vulnerability of political leaders to extremes of public opinion, particularly the emotional desire for a punitive peace settlement after such a painful wartime experience and the continuation of the myth that the debts accumulated during wartime could be repaid. But he gave most space to criticizing US President Wilson and his advisers, claiming that he was under-prepared and therefore lacked decisiveness. He was even critical of his physical appearance; his description of Wilson as being more impressive when he was sitting down rather than standing was a metaphor for the position of the US in the global system - seeming important when at rest, but not very impressive when it came to taking action. His portrayal of Wilson on the one hand as a sophisticate in terms of his dress but on the other hand the body beneath this façade 'lacking in fine-ness' might also reflect a view of the US as seeming to have become modern and as sophisticated as Europeans, but not having fully made this transformation from rougher stock. cBy 2016, once again in the United Kingdom it seemed that Keynes' observation in 1919 that "Europe is apart and England is not of her flesh and body"” was emerging as a defining ideology. In sum, the pendulum has swung from the gold standard and the first era of globalization, through the bleak thirty years war and its aftermath, back to the Great Moderation and the second era of globalization. This pattern has resonance to Keynes' views on international monetary relations. The gold standard was buttressed by a rule that subsumed internal (domestic) balance to external balance. That helped foster the first era of globalization. 
Tensions from this arrangement became manifest in the nationalist backlash in the first half of the twentieth century and the shift of focus to the dominance of domestic considerations and autarky (tariffs and capital controls). Keynes' contribution to the post-1945 era was a rulesbased arrangement to reconcile internal with external balance. With extensive international cooperation and tinkering it worked for two decades but it broke down primarily because of the failure of the centre country, the U.S., to follow the basic rule of maintaining price stability. In subsequent decades after the failure of the advanced countries to follow domestic macroeconomic policy rules to maintain price and exchange rate stability which created the Great Inflation, the advanced countries have returned to a rules-based system under floating exchange rates based on CBI, IT and credibility for low inflation. These features characterised the Great Moderation, but also allowed a complacency about the governance of international financial markets that sowed the seeds for the next great global crisis in 2007-08. There is considerable resonance to the pre 1914 gold standard that fostered the first era of globalization. Then just like the first era, a backlash emerged against the adverse effects of trade integration and financial globalization following the GFC. It in turn reflected, failures in financial regulation, monetary policy, and global imbalances. We are back to viewing the second era of globalisation as fitting Keynes' description of the first era as "Unusual, Unstable, Complicated and Temporary". Will the world get back on the track of the pre-crisis era or go in a similar direction Keynes prophesized in 1919 for the post World War I era? The fourth turning point in the international system is still incomplete, but following from Keynes, history reminds us that nostalgia for an earlier period needs to be tempered by a realistic understanding of how 
"unstable, temporary, complex and unreliable" were the golden ages of international economic cooperation. 


\section{References}

Albers, Thilo N.H. (2020) 'Currency devaluations and beggar-my-neighbour penalties' Economic History Review 73(1) 233-257.

Arndt, H.W. (1944), Economic Lessons of the Nineteen Thirties, London: Frank Cass.

Bernanke, Ben S. (2015) The courage to Act: a memoir of a Crisis and its aftermath, New York, W.W. Norton.

Bordo, Michael, Eric Monnet and Alain Naif (2019) "The Gold Pool (1961-1968) and the Fall of the Bretton Woods System. Lessons for Central Bank Cooperation" Journal of Economic History December

Bordo, Michael ( 2018) " the Imbalances of the Bretton Woods System 1965 to 1973 : US Inflation, The Elephant in the Room" NBER Working Paper 25409. December Bordo, Michael (2017) “The Second Era of Globalization is Not Yet Over: An Historical Perspective" NBER Working Paper.

Bordo, Michael and Christopher Meissner (2015) “Growing Up to Stability? Financial Globalization, Financial Development and Crisis" NBER Working Paper 21710 (June) Bordo, Michael and Pierre Siklos (2015) “Central bank Credibility: An Historical and Quantitative Evolution." Chapter 3 in Central Banks at a Crossroads: What Can We learn from History? (eds) Bordo, Michael, Owen Humpage and Anna Schwartz (2015) Strained Relations: US Foreign Exchange Operations and Monetary Policy in the Twentieth Century. Chicago: University of Chicago Press

Bordo, Michael and John Landon Lane ( 2013) “ Does Expansionary Monetary Policy Cause Asset Price Booms: Some Historical and Empirical Evidence" NBER Working paper 19585. 
October .

Bordo, Michael and Athanasios Orphanides (2013) The Great Inflation. Chicago: University of Chicago Press

Bordo, Michael and Harold James (2002) “The Adam Klug Memorial Lecture: Haberler versus Nurkse. The Case for Floating Exchange Rates as an Alternate to Bretton Woods" in Arie Arnon and Warren L. Young (eds) The Open Economy Macromodel: Past, Present and Future. Boston: Kluwer Academic Publishers pp161-182.

Boughton, James M. (2011) Silent Revolution: the International Monetary Fund 1979-1989, Washington: International Monetary Fund.

Clavin, Patricia (2013) Securing the World Economy: the reinvention of the League of Nations 1920-1946, Oxford: Oxford University Press.

Clarke, Peter (1990) The Keynesian Revolution in the Making, 1924-1936, Oxford: Oxford University Press.

Davidson, Paul (2009), The Keynes Solution: The Path to Global Economic Prosperity. Emil Despres, Cahrles Kindleberger and William Salant (1966) "The Dollar and World Liquidity: A Minority View" Economist 5 (February); 526-29.

Eichengreen (2018) The Populist Temptation: Economic Grievances and Political Reaction in the Modern Era. New York: Oxford University Press.

Eichengreen, Barry (2015) Hall of Mirrors: the Great Depression, the Great Recession, and the Uses - and misuses - of History, Oxford: Oxford University Press. 
Barry Eichengreen and Marc Flandreau (2009) "The Rise and Fall of the Dollar (Or When Did the Dollar replace Sterling as the Leading Reserve Currency?" European Review of Economic History Vol 13 , number $3: 377-414$

Eichengreen, Barry and Timothy Hatton (1988) "interwar unemployment in International perspective: An Overview" in Barry Eichengreen and Timothy Hatton (eds) Interwar Unemployment in International Perspective. NATO ASI Series (Series D: Behavioral and Social Sciences) Vol43. Springer; Dordrecht.

Eichengreen, Barry (1992). Golden Fetters. New York: Oxford University Press.

Fogleman, Aaron S. (1998) 'From slaves, convicts and servants to free passengers: the transformation of immigration in the era of the American revolution' Journal of American History, 85(1), pp. 43-78.

Friedman, Milton (1953) "The Case for Floating Exchange rates 'in Milton Friedman. Essays in Positive Economics. Chicago; University of Chicago Press pp 461-494.

Gardner, Richard N. (1956) Sterling-Dollar Diplomacy, Oxford, Oxford University Press.

Giovannini, Alberto (1993) "Bretton Woods and its Precursors: Rules versus discretion in the History of international monetary Regimes' in Michael Bordo and Barry Eichengreen (eds) A Retrospective on the Bretton Woods System: Lessons for International Monetary Reform. Chicago; University of Chicago Press.

Goldberg, Linda, Craig Kennedy and Jason Miu (2011), 'Central bank dollar swap lines and overseas dollar funding costs' Economic Policy Review, May, pp. 3-20. 
Goodhart, Charles (2011) The Basel Committee on Banking Supervision: A History of the Early Years. Cambridge: Cambridge University Press.

Horsefield, J. Keith (1969) The international Monetary Fund 1945-1965: twenty years of international monetary cooperation, Washington, International Monetary Fund.

International Monetary Fund (2012) The Liberalization and Management of Capital Flows - an Institutional View, November 14. https://www.imf.org/external/np/pp/eng/2012/111412.pdf (accessed 9 October 2019).

Irwin, Douglas (2012) Trade Policy Disasters: Lessons from the 1930s. Cambridge : MIT Press James, Harold (1996) International Monetary Cooperation since Bretton Woods, Washington: International Monetary Fund. James, Harold (2001) The End of Globalization: Lessons from the Great Depression. Cambridge: Harvard University Press Kaldor, Nicholas (1971) "Conflicts in National Economic Objectives" Economic Journal Vol 81 Number 321 (March): 1-16.

Keynes, John Maynard 1944) Proposals for an International Clearing Union John Maynard Keynes (1933) “ National Self Sufficiency” Dublin: Educational company of Ireland Keynes, John Maynard (1930), A Treatise on Money. London: MacMillan Keynes, John Maynard (1925) The Economic Consequences of Mr. Churchill. London MacMillan Keynes, John Maynard (1919) The Economic Consequences of the Peace. London MacMillan 
Kindleberger, Charles (1975) The World in Depression 1929-1939. Berkeley: University of

\section{California Press}

McCauley, Robert N. and Schenk, Catherine R. (2020) 'Central Bank Swaps Then and Now: swaps and dollar liquidity in the 1960s' BIS Working Paper, 851.

McCauley, Robert N. and Schenk, Catherine R. (2015) 'Reforming the International Monetary System in the 1970s and 2000s: would an SDR substitution account have worked?', International Finance, 18(2), 2015, pp. 187-206.

McCauley, Robert N. (2016) 'Does the Dollar Confer an Exorbitant Privilege?' Journal of International Money and Finance 57, pp 1-14.

McKinnon, Ronald (2015) The Unloved Dollar Standard. New York: Oxford University press Meltzer, Allan (2010), A History of the Federal Reserve. Volume 2. Chicago: University of Chicago Press

Milward, Alan (1999) The European Rescue of the Nation State Routledge. Berkeley: University of California Press

Nurkse, Ragnar (1944) International Currency Experience. League of Nations Moure, Kenneth (1996) 'Undervaluing the Franc Poincare', Economic History Review, 49(1). Ostry, Jonathan D., Atish R. Ghosh, Karl Habermeier, Marcos Chamon, Mahvash Qureshi and Dennis Reinhardt (2010) Capital Inflows: The Role of Controls, IMF Staff Position Note, February 19. https://www.imf.org/external/pubs/ft/spn/2010/spn1004.pdf (accessed 9 October 2019)

Pauly, Louis W. (1996) 'The League of Nations and the Foreshadowing of the International Monetary Fund' Essays in International Finance, 201, December. 
Pressnell, L.S. (1987) External Economic Policy Since the War Vol. 1: the Post-War Financial Settlement, London: HMSO.

Roberts, Richard (2013), Saving the City: The Great Financial Crisis of 1914. Oxford: Oxford University Press

Rockoff, Hugh (1984) "Some Evidence on the Real Price of Gold, Its Costs of Production and Commodity Prices "in A Retrospective on the Classical Gold Standard" (eds) Michael D Bordo and Anna J Schwartz. Chicago: University of Chicago Press

Rueff, Jacques (1967) "Increase the Price of Gold" in Lawrence H. Officer and Thomas D. Willett (eds) The International Monetary System: problems and Proposals. (ed), Englewood Cliffs, NJ: Prentice Hall.

Schenk, Catherine R. (2019) , 'International Monetary Cooperation since the Global Financial Crisis' in C.R. Schenk and M. Klein, IMF's Work on Encouraging International Policy Cooperation, International Monetary Fund, BP/19-01/06.

Schenk, Catherine R. (2017) 'Coordination failures during and after Bretton Woods', in M.

Qureshi, A. Ghosh ed., From Great Depression to Great Recession: The Elusive Quest for International Policy Cooperation, Washington: International Monetary Fund.

Schenk, Catherine R. (2014) 'Summer in the City: banking scandals of 1974 and the development of international banking supervision', English Historical Review, 2014, pp. 11291156. 
Schenk, Catherine R. and John Singleton (2011) “ Basket Pegs and Exchange Rate Regime Change: Australia and New Zealand in the mid-1970s" Australian Economic History Review 51(2) pp 120-149.

Schenk, Catherine R. (2010) The Decline of Sterling: Managing the Retreat of An International Currency 1945-92. Cambridge: Cambridge University Press.

Skidlesky, Robert (2009) Keynes: The Return of the Master. London: Penguin Press.

Silber, William (2007) When Washington Shut Down Wall Street: The Great Financial Crisis of 1914 and the Origins of America's Monetary Supremacy. Princeton: Princeton University Press. Singleton, J. (2011) Central Banking in the Twentieth Century, Cambridge: Cambridge University Press.

Solomon, Robert (1982) The International Monetary System 1945-1981, New York: Harper and Row.

Steil, Benn (2013) The Battle of Bretton Woods: John Maynard Keynes, Harry Dexter White, and the Making of a New World Order, Princeton, Princeton University Press.

Taylor, John B (2007) “ Housing and Monetary Policy" Remarks at the Federal Reserve Bank of Kansas City, Jackson Hole Economic Policy Symposium: Housing, Housing Finance, and Monetary Policy. August.

Peter Temin (1989) Lessons from the Great Depression. Cambridge: MIT Press.

Benn Steil (2018) The Marshall Plan: Dawn of the Cold War. New York: Simon and Schuster Toniolo, Gianni (2005) Central Bank Cooperation at the Bank for International Settlements, Cambridge: Cambridge University Press. 
Triffin, Robert (1960) Gold and the Dollar Crisis. New Haven: Yale University Press

Edward Truman (2009)

Wheatley, Jonathan and Peter Garnham (2010) 'Brazil in 'currency war' alert', Financial Times, September. 